NINA BURRIDGE AND CHRISTINE EVANS

\section{MAGENTA SECONDARY SCHOOL}

CONTEXT

Mascenta Secondary school is located on the northern shore of Sydncy with

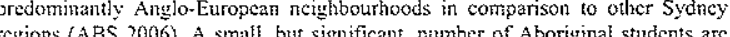
chrolled at the schoon. Some students are drawn from the local area with others coming from nurat and regional New South Watcs. Aboriginal students attend the schoot for various periods of time. ranging from less than a term to several years. Whilc attinding the school the minjorty of Aborigntial students lived in a nearby mostel with Abonghnal house parchts who drcsect the optrasons of the hostel, sttudents parents or carers in their thome community. A smaller percentage of Aboriginal students at the school are from familics that are well estabbished locally. Throughout the project the school mantatined their established connections with the hostel staft and several local Aboriginal comsunity members including some who worked in oher cducalional institurions such as the Techical and Further Education weal Aboriginal community to vather, hold mectiuss and events. The Aboriginal Learninu Centec houscs a permanent Aboriginal culbural objects colicction and host exlibitions of artworks. The Aboriginal students were frequently involved in tcaching flearning activitics at the Aboriginal Lcarning Centre.

\section{MPLLMENTATION}

The action icanning team at Maycnta School initially compriscd scveral nonAborigiral teachers fonc of whom was responsible for the management of the projecl). one librariant, an Aboriginal Education Officer and an Aboriginal community partner endorsed by the focal Aboriginal Education Consultative
Group. The deputy principal was also very supporive and involved in the carlicst unfolding of the action learning project. Over time, for a range of reasons. this membership crperienced chanye as did school maner

Marenta Secondary School initially commenced the action leaming project activitics collaboratively with two nearby primary sclwoits with a shared academic mentor. The three schoosis had in common the fact that the majority of Aboriginal students resided for sthort or longer periods in thes way fom their conmunimesolong

the Aboriginal acto

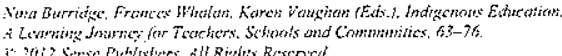

Ihree schools. The three schools developed teaching and learning activitics with the overarching titic of Narrative ldentigy and Place. By the end of the first year. the projects onds across the three schoofs became increasingly differentiated and

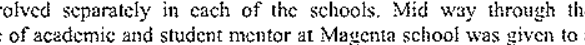
beal Aboriginal educator and comnenty member with exlersivive teaching expericnec. This provided teachers with the added advantage of having casy aeces the local arca.

Phase 1

The first phase of the project involved cross-school collaboration with a number of the Magenta Secondary School Aboriginal students indertaking work experience placenents at one parner primary school to enhanec iheri ceadership. self-estecm Representatives of a locil Aboriginal cduction organistion obsered the progen of those students noting that they became 'so much more confident'. Creative arts initiatives were instigatcd in the initial phase with those Magenta School students

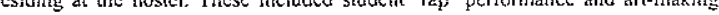
tof

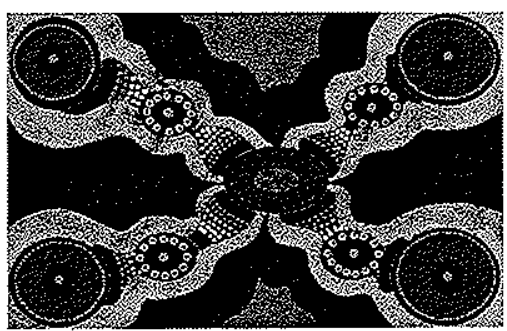

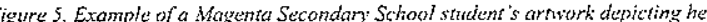
strength, in her journey from community to community.

Phase 2

As noted above, during the second phase of the project, the two primary schools and thc sccondary school separated their project activitics into threc independen and secondary school orvunistional requircments, such as staff releasc patterms 
MAGENTA SECOSDARY SCHOOL

and curricidum structures. The differing approaches within the broader project and curriculuni structures. The difering app

White all project teams were provided with project dircetions and resources. Magcenta School identificd some initial difficultics in establishing the direction of he project and what was required under the NSW Board of Studics syliabus
requirements. One participant said "it did need a stronger framework to begin with - because it was a little bit like seff-discovery lcarning - and we went off into directions that the project officers didn't perceive as important". After the team's

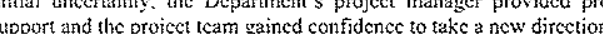

In the first two phases of the project. the focus had becris to apply the principles of action Icerning and Quality Teaching with two key questions in mind:

- What do tcachers need to know to improve Aboriginal stadents" cducational outeomes?

- How might the inclusion of cultural knowledge improve Aboriginal students cducational outcomes?

\section{Phases}

In phase shree of the project the school focused on the second question, though the two can be seen to be intercelated. The foctus shifted to developing the students' Information and Communication Technologics. Students' personal storics became e-parratives incorporating $t w$ Design. Photoshop, Wervin and other programs to suild interactive stories of their Country and family. Students" cultural heritage and knowledge were captured in their portfolios, reflected in their personal fearning

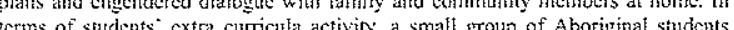

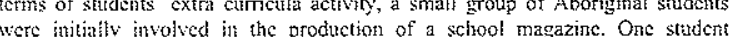
sustained that involvement. Her experience is reported to have been very positive and she is able to now mentor others

The employment of a local Aboriginal community member as a casual teacher at the schoof impacted favoribly on the devciopment of the project. She fullilised important rojes as "Alunty" and teacher to the cohor of female Aboriginal

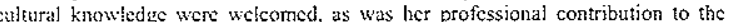
project tearn and other teachers at the high sethood. She was able to crgagec stuidents in identifying a range of relevant teaching and leanting activitics that integrated Aboriginai cultural knowstedge. These activitics were developmentally appropriate and gender sensitwe. incorporating sylabus requirements. A number of her oun trdigertions biecrary arts and law provided positive mentroring and motivation to the schoors Ahoriginal students.

\section{N. BURRIDGE AND C. EVANS}

The Aboriginal teacher and community member assumed the role of academic partner to the project team. In this new capacity many positive changes occured
through increased opportunitics to work with both Aboriginal and non-Aboriginal
students and tcachers to raise awareness of Aboriginal cultures ind bistorics in the students and teachers to raise awareness of Aboriginal cultures ind historics in the school.

With an experienced Aboriginal teacher and librarian on staff, the action leaning team was able to concentrate on cinbcdding Aboriginal perspectives into Key Environment in the junior secondary curriculum. A Ycar 8 Tcchnolecy Lint was based on the contemporary batik works produced by women from the Ernabelia community where the Technology and Applice Studics teacher had previously workcd. The unit, which included an interactive whilc board presentation linked wish workshects for students to complete, was designed so that all teachers could use it. This approach was used across the school. It was described as being based on tho if they had limited knowledge of Aboriginal cultures. Units of work forctrounding Aboriginal cultural knowlcdge were introduced into Scicnce (Year 8). Gcography (Year 9), English (Ycars 7 and 8), Creativc Arts (Ycar 8) and Languages (Ycar 8). By the close of the project, hie take-up rate of suoject areas incorporaling Aboriginal perspectives had cepanded and teachers across Key Leaming

IMPACT

The implementation of the projcct at Magenta cnhanced teacher professional carning in a number of ways hal knowicd ac.

Participation in Professional Development

A survey of teachers (sce Appendix) indicated that staff participalion in professional development on Aboriginal dacation grew from $60 \%$ lo $75 \%$ over a nvelve-month period. There was an merease in the extent to which stafi cngagement whth the Aboriginal conmunity was impacting on their teaching Among staff who
from $6 \%$ to $15 \%$.

As a result of these activities, there was an increase in staff who had adjustcd their teaching strategies for their Aboriginal students and inctuded Aboriginal cultural knowiedge into their leaching and were more inclined to aceess the con $35 \%$ rose from $35 \%$ to $36 \%$. The proportion that said their teaching practices werc The resources accessed from the local Aboriginal community also increased from $30 \% 1044 \%$ in the 12 months period. 
Teacher insivghts

Bearing in mind the different levels of expericnec and confidenec in working with Aborignthat communities, the project did develop the teachers understanding of the Quality Teaching modci. It appeared that embedding Aboriginat cultural Mirowledgc within specific Key Learning Areas through the Quality Tcacling part of the mainstream curriculum. The project tcam leader explained how:

including Aboriginal cultural knowtedge fultils many of the dimensions of Quality Teaching - and this fact is very reassuring to tcachers who arc its place in the mainstream curricula.

Another exantole of one teacher's experience of change in practice is described below:

Amongst the many mistakes ['te made is I tsed to write a letter to the girts' parents. ...t didn't occiar to me that they would open the letter with the they didint read it So wc've becn frantically ucting ictters of conmendution home and two grandinas have nung, well they ve rung the hostcl manager. to say that they are so happy to see these non-threatening [cornmens].

The opportunitics created by the regilat presence of an Aboriginal teacher, unatlached to a specific Key Lcarning Area, supported a range of positive outcomes. Whilc the development of Aborigimal perspectives across the curricuitum at this school site had been an aspiration of the project feam manager for several
years, and had becr promoted as desirous to whole school audiences over time, only a fow teachers prior to the project had developed these understandings.

the lcat their focus on contemporay issucs - ceren simple things like the necd to whknowicdge Country - helped all students to become more confident with Ahorignial cultures. The prinepal encourayed the Student Representative Council to fly the Aborigmal flayt. was approacllabic and took an active interest in Aboriginal studen Thenginal issters.

al and Applicd Studies tcacher's capacity to use interactive rated the rolc of the reilly brought the material to lifc. Again the tcacher Applicd Studies program "...my personal knowledge was crntanced... [she] willingly shared resources and knowledge to enrich the delivery of units to all

The Aboriginal teacher's appointment as academic partner, enabled her to act cornmeunication skills were welcomed by scveral Icachers, representing a range of
N. BURRIDGE ANDC. EVANS

discipline areas, and assisted them in their incorporation of Aboriginal cultural

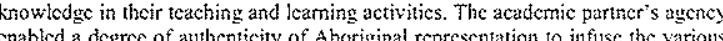
streams within the project.

The inclusion of tnits of work in Key Learning Arcas resultcd in an increase in the quality of curriculum resources in Technological and Applicd Studies. English and Personal Development, Health and Physical Education. The English teachers

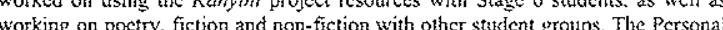
Dcvelopment. Health and Physical Education teacher lookcd at various Aboriginal health issucs.

Another positive outcome of the project was the updating of teaching resources in Aboriginal Studics and increased accessed through the library. An audit of the resources ensured that they were culturally appropriatc. The academic partner was establishing a "rcally meaningfus and relevant Aboriginal collcction Working with the academic [partmer] has been 'invaluable in that sic fras shared her cxpertise of Aboriginal [resources]...she has cvaluatcd our collection from a unique perspective as an Aberiginal woman, academic and librarian"

Greater Level of Strdent Engagemen

Teachers noted a higher fevel of student engagement as they felt more confident Tcachers noted a higher level of student engagement as they felt more confiderit
and motivated to learn about Aboriginal culture. They also felt that it provided
students with a greater focus on contermporary Aboriginal cultures. Teachers were now including cultural knowledge into assessment.

There was a great display of Aboriginal students' confidence because their culture was being highlighted. This was reinforeced by the Aboriginal officer at the hostel who had the role of supporting the students whilc they were at the

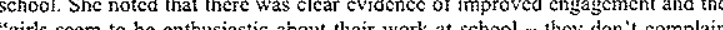
" bout staying at school, Her vicw was that ". we really have produced a grood year - hardworking ycar - but I fecl that everybody has achicved something positive".

Teachers aiso noted increased interaction across the student population with the Aboriginal students:

...there is more interest and a whole lot more talking about it - and more interest in the background [of the] girls - people know that it is going on.

In addition to the above, one non-Aboriginal teacher interviewed noted the work done by two Aboriginal students on the school journal raised awarencss of the contribution Aboriginal students were makking to the school. It also helped the Aboriginal students to expand their actsvitics beyond their 'Aborigittal group' from the hoste. 
MAGENFA SECONDARY SCHOOL

What was Learwed in Whorking with Ahoriginal Coumunities and Students about Ahreriginal Citlural Knowitedge

The project activities yenerated a nurnber of incremental changes. Changes were noted in strdents" approach to school and in their level of expositure to and awarenes

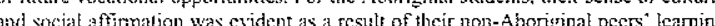
whouth Aboriginal cultural knowledse and having Aborigital cultural conten integrated as part of their everyday classrom experience. While the strudents atways

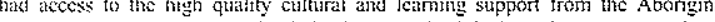
Educution Officers it the school, having an Aboriginal teacher as an academ dimension in the project.

Key Factors in Supperting Ahorigtinal Sendents and Ahoriginal Prograns. in Schools

A supportive principal and effective excetilive leadership in the school were consiciered to be very important factors in the success of the program. The action learning teims at Waycenta schrol received strong and continued support from the priscipal. sceing it as a key policy reform for the sehool. The project team Icader effectively and was responsive to the team's meeds by involving an Aboriving tcacluer librarian in the project. She also demenstratced leadership and nerofiation skills in supporting that lesther's transition into the roic of academic partner. Project furding provided support for the time needed to address the chattenges along with the professional carning necded in adapting "establishod" curricula in changhing work patterns. The project developed a grealer schse of profsssionalish they valued the extra time they were able to devote to refiection on the

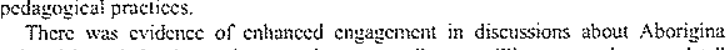
cutural knowldye by project menbers. as well as a willingness to feam and tall

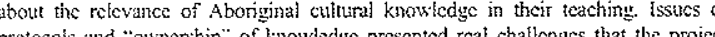
protocols and ownership of knowledge prescnted rcal challonges that the project centure of the project was the increased communication between the sclool and the stridents" hotne communitics. The project leader commented in November 2008 " we had some grandmas ring up and say 'we have never had the girls so setticd.

$$
\text { Consulftation and Collaboration with Aboriginal Commutuity }
$$

As nuted carlicr. schools are busy places, and the eapacitics and opportunities for the action fcarning team to engage and parther with the local Aborigina local Aboriginal commusity, how they perceived the community, and the
N. BTIRRIDGE ANDC. EVANS

processes they put in place to link and support involvenent with the community. foxitics arose from the fact that most of the Aborigin members, redefining 'the loos A both the direction and the extent to which the school consulted with their resident local Aboriginal community.

Eariy in the project, a teacher identififed the "local Aboriginal community" as 'the

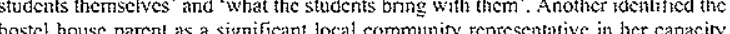
as a substitute parenticarer and legal grardian for the sludents while at school. The school regarded the substitute parenticarer as the key conmintrity member for the purposes of consultation and tiaison in the project. To some extent this led to icsser isvolvement in the project of the local Aboriginal Education Consutative Grotp

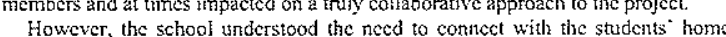
communities as did the Department and other focal Aboriginal community members. This enabled teachers to support student rescarch aboul their own local Cotntries as scttings for their school assiguments. An exampic of this related to the students" work on digital narratives that linked their loome conmmunitics and their

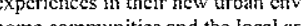

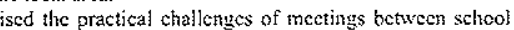
slaff and local Aboriginal community organisation members. Staff from the school worked during school hours, while many community represcntatives attended their the local Aboriss in the evenings. Durning the project phases, represciratives from visits werc largely for presentations and not for project or other school planning. The tcam members also contributed to the achicvement of many youls by Departmental Aboriyinal Education Consultant to respond to the profession enquiries of the team and the schood staff generally. The team members also reporte Seral members of the local comminity inchding from the locel Aborigint Education Consultative Group were critical of the lack of active consultation on the part of the school duning the life of the project. One representative explained later that this rendered "the local Aboriginal community " " "wasted resource". It only contributed to, as one participant described, the inaccurate perepption of the

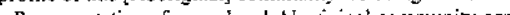

" corction and proyress of the project was inadequate over the life of the project. Some Aboriginal community participants identified the theed for regular project loam mectings to be arratiged with greater notice. Similarly, the development of a 
opportunitics for the academic partncr. team members and conmunity representatives to collaborate in the project planning.

Understandings of Ahoriginal Cultural Knowledge

The team mernbers reported that they had conbented their understandings of Aboriginal cultural knowledge. Howerer. at his school site there were complexities that arose from the unique residential nature of Aborignnal student" guestions of whose cathrot knowlede was accessed to inform the school's perspetives on Aborigina! cultural knowledge which werc being constracted through the work of teachers in the school.

White the variouts 'home' cuthures of the students were acknowledged, and efforts made to acess that knowledyc, the team found it difficult to access thern distance. Most found that communicating with regional co

Aboriginal cultural

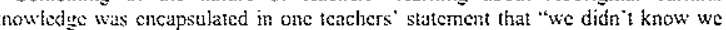
conk pur in a [Googicl scarch for Barkindji the regional Aboriginal language

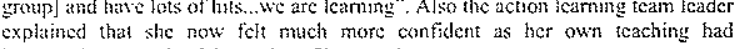
will of the project. She slated:

My personal knowledge now intluences my ability to communicate my kriswicdyce. my cxperience, my respect for traditional cultural knowledge to

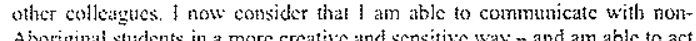
An is their bridge betwecen the dominase mon-Aborignal cumculum and Asserrive in the inclusion of Aboriginal criltural knowledge resources in the çassromm.

As stugested earlier, mid-way through the project, a member of the local Aberiginat commanity assumed the rolic of academic partner and as a result the fessurec audit took place culminating in the developinent of a dedicated library location for books on Aboriginal cultural knowiedge. This complemented the gradtal 'take up' of opportunifics for cnhanced stapport for integrating Aboriginal they fett more confident in introducing sborivinat perspectives in their units of work within their Key Learning Areas. According to the academic partncr "changes have ocectrred in the ethos of the staff... [there has bectil a growing comprehension of the Aboriginal and Torres Strait Islander content and Quality Teaching"
Barriurs, Challenges and Opportunities

Time constraints are acknowledged as a universal challenge whrn new and intovative programs are introduced - this project was no exception

Implementing the project was perceived as inereasing teachers' workload, but in the ender well I probably would have I gucss... had we realised the amouns of work ... it's secn as an cnormous amount of work". The willingness of staff to be involved was supported by adcquate resourrecs for staff relicf and meetings. It was acknowledged that without the funding the project conld not bo sustained indefinitcly.

The challenge for cachers to connect the project to syllabus outcomes was identicd as a challenge. The Abonghal academice parner played a key role in a need for resources of sufficient academic rigour tor various senior hight school syltabus documents, and the academic particer was able to help with some subject arcas, such as Dance. The academic partner was able to locate a former National
Aboriginal Islander Skills Devclopment Association dancer who provided Aboriginal Islander Skills Devclopment Association
appropriatc cultural support and guidance to the teachers A The Abonginal academic partner also notcd that sample units of work forcureuriding Aboriginal cultural knowicdye were not yet available to teachers from the Board of Studies New Sorth Wales websitc. allong with other sylabus support material, At this site and among many other sites the limited avaliablity of these kinds of resources proching and lezming resources represents a key challenge for fature efforts to support The connections the school could make with the parents and the home communitics of their Aboriginal students were very important to the ongoing cfforts to improve student leaning. The ability to cornect effectiscly with the

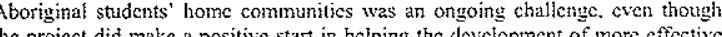
contacts. A futher challenwe was how to sustain the progran orec the sudents who were part of this project refumed to their home communitios.

The chatlenges relating to interpretations of who constituted the local Aboriginal community have becen noted and perhaps reguirc further discussion and debatc. Negrotiating appropriate collaboration and consultation betwecn the school and the local Abongal Edoul

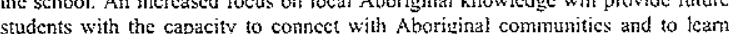
about the local cultural herilage. which in tum will enrich broader perspectives on

Aboriginal history and culture.
The tcam leader noted the necd for further professional development for cachlors across Key Learning Arcas to cnsure that Aboriginal cuiturn Inowledge 
MAGENTA SECONDARY SCHOO

There is still resistance to include Aboriginal cultural knowledge in some areas. but I think that will be overcome when we do the cultural werkshops the new Aboriginal Education Policy.

For the school and its future development within the local community. it was the local Aborival to declop and maintain comnections with active members programs and dcvelop opporturitics for expanding understanding of loca Aboriginal knowledyc.

Leadership

The stipport of the priseipal to the goals of the project. even thotgh she was no dircely issolved in the day to day runbing of the project was crilical. In the initio plase the deputy-principal led the tean, at the mid point of the project, the role was transfered to the head teacher (Adninisitration). The project team leade stecessfulty negotiated the appointunent of the Aboriginal academic partnce. In lemends on the cum and to make the necessary structural changes, baved upon her own craluation of the project's dircetion.

$$
\text { Rale of Mentors and Other Conamunin Based Groups }
$$

The project had two different academic mentors. The first Aboriginal academic menter was ahthated with a regronal universty some distance fiom he school. He espects of the initial project collaboration among the three original schools involved The project team leader noted the acedemic parther's "wonderful idca" to have the students also "work with their communitice". The development of the students" Personal Learning Programs digital naratives indicalcd the success of this suggestion. which gencrated qualify outcomes for both students and staff. This

noted "the project has given us the opportunity to work wilh the local community and work with an acadennic partner who has becn able to guirde us and make suggestions ... he contribution has been invaluabic and has given us the confidenee to find our ow

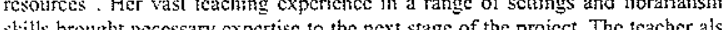
atce additiontly, the advantages of having an academic partiner who resido clase to the school. This helped with networking and with a more informed awarencss of the locil community. Her experience as a teacher meant that she also recognised teachers' busy sehedulls. Across the 21 schools in the overall project

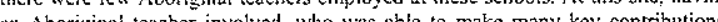

X. BURRIDGE AND C. EVANS

was highly valued. She stated that "wce, Aboriginal people, coming in on a project. arc your equats and wo wish to work with cqual, mutual respect". Another agent and stakeloloder was the Departmental Project Manascer who The school tcam leader reported that Magenta Seliool found the inprecedented nature of the project somcwhat difficutt to adjust to initially, and it took time before the project developed the momentum achicuce in the frial phase. The role instrumental in progressing the project beyond its carly phases, providing the guidance to continuc it to complelion. As one participant noled "we would be where we were 5 years ago if not for the project - a huge part of that is the personal commitment for the project learn members from DET

\section{Sustaining the Project}

One of the main probicms with goverminest funded initiatives is that invariably when external funding ends, the project is scaled down. Sugycestions for continued support involve collaborative partncrships with a regional Aboriginal Education consultant to organise staff devclopment days, to cxpand the range of resource sitcs
for tcachers to access, and to assist individual teachers to place Aboriginal cultural knowledge perspectives into thcir units of work.

A continuing emphasis on the importance of contemporary cultural knowited and in kecping with Departmental Aboriginal Education policy devclopmen supported this process. The need to continuc the increased conncetion with sudents' familices in their home communities to build o by the tcam was scen as a priority for sustainability.

For chl wanced partnership wh local Aboriginal organisations and some scrice share the extra curricula commitmenl of attending enembers and or other staff to workload adjustment to support tcachers' commitments to commumity mectings. Grcater exposure to a range of models of consultativive practices for working with bonginal communtics would also be of value to schools like Magenta

Chic Department or Education's grats omplasis on mformation and the project to be further revitalized by using technologies such of video conferencing. It was noted that by using this technology, students from Magenta Sccondary School werc confidently teaching other students in oller schoois about Aboriginal cultural knowlcdge.

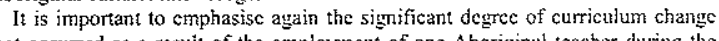
that occurred as a result of the cmployment of one Aboriginal teacher during the
project. If further progress was to be made in the devclopment of Aborignal perspectives, one way to support that would be for the school to continuc to maintain its efforts to employ Ahoriginal tcachers and para-professionals. 
CONCLLSSON

In stunumary. the project undertaken in this sehool was successful because several critical factors came together to build connections betwecn teachers and studen and their Aboriginal communities. There was a willngngness to integrate the projce ho school activity particularly in tems of allowing time for teachers to conc time allowed teachers to wain new insights into their teaching facifitating a greater understindling of local Aboriginal cultural knowiedgc. Sndents were visibly mor cngetged and teathers were excited by using new technologies to crhance student

The project benefited from a supportive exceative leadership and this was a key factor in the overall steccess of the project as it yave the projcct authority within the actor that contributed to the project's suecess. On the other hand challentes aciuded: ticeding to work with the exeryday pressures of school routines and limetabics and an overcrowded curriculunt. mannaining good connections with parents: and the locat Aboriginal contmenity as well as sustaining the project

Overall however. much was gained by teachers in their learning journey towards . carriculum.

REFERENCES

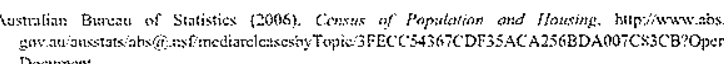

